\title{
Nucleopathy, The New Dimension of The Allopathy
}

\author{
Shahid Hussain Sheikh, MD, PhD* \\ NIDS Treatment \& Research Center, Pakistan
}

Received: May 11, 2018; Published: May 21, 2018

*Corresponding author: Shahid Hussain Sheikh, MD,PhD, NIDS Treatment \& Research Center, Pakistan

\section{Introduction}

Conventionally, the understanding of any given human ailment aligns with system to organ to tissues, membranes and cells. We call it "CytoPathology", we engage in a variety of diagnostic tools to evidence such Cyto-pathology to confirm our diagnoses and tailor a medical or surgical plan according to the given established protocols. Atomic Force Microscopy (AFM) has brought a new paradigm in the view to best clear our understanding of the emerging pathophysiology of a given symptomatic pathology [1]. No more we can logically treat a disease based on the symptomatic realm of outdated guidelines, adhering to "Etiology Unknown". Today, majority of the ailments have only symptomatic relief/ treatment. There is an urgency to take a deeper look at the source of ailments and try to define the possible etiology for a better, comprehensive and a permanent relief to the ailing humanity. Nucleus of a given cell being the controlling entity for that cell's homeostasis, its timely development and its functions, So is true of the controlling Neurons of the Brain.

In 2004, Late Dr. Edward Wagoner and his team at the University of California at Irvine did not fathom the idea that they were about to change a paradigm of etiology [1,2]. His team Dr. Alex Malkin, Dr. Alex McPhearson and Dr. Marco Plomp used the AFM and revealed the real time "Nano-Pathological" series of events that Dr. Wagoner reported in his last publication [2]. I was fortunate to have this opportunity to evaluate their findings clinically and integrate into the clinical practice to best diagnose and help alleviate the symptoms and neopathogenesis, that help prevail the homeostasis of cells, tissues, organs, system that promote the quality of life. Cyto-pathology is no longer an absolute reliable tool to finalize the proper diagnoses. Currently, so called treatments are merely a symptomatic pacification to borrow time for the resident immune system to recongregate/ revitalize against the pathogens in question. The Nucleo-pathology of the controlling neurons indeed is the paradigm shift, the grass root Instigator of the basic symptomatology that results into the disruption of the normal homeostasis [3].
However, pacifying the symptoms is not the final treatment of the chronic ailment. On the contrary it is the opportunity given to the pathophysiology to continue to grow into a bigger challenge, eventually becoming an incurable disease. To date, this phenomenon has been a hidden secret of nature. Now that is opened, it is unraveling the possible etiologies of the unknown nature of the conventional diseases (Table 1). The "Sheikh's Syndrome", is rightfully a very well established guideline to see any disease's root cause etiology and possible treatment to eradicate the ailment [4].

Table 1.

\begin{tabular}{|c|c|c|}
\hline \multicolumn{3}{|c|}{ Diseases Linked to the Nucleopathy 3,4} \\
\hline ADD & *Allergies & *Alzheimer \\
\hline Amenorrhea & *Anemia & *Aneurysms \\
\hline Atherosclerosis & *Asthma & $\begin{array}{c}\text { *Bell's \& Cerebral } \\
\text { Palsy }\end{array}$ \\
\hline CAD & *Cancer & ${ }^{*} \mathrm{CFS}$ \\
\hline Cognitive Disorder & $\begin{array}{l}{ }^{*} \text { Chromosomal Dis- } \\
\text { order }\end{array}$ & *Diabetes Mellitus \\
\hline Encephalitis & *Endocrine Disorders & ${ }^{*}$ Gastroenteritis \\
\hline Gastric Ulcer & *Gynecomastia & *Hypertension \\
\hline Hypohemoglobinemia & ${ }^{*}$ Hyperlipidemia & *Hypothalamic Dysf. \\
\hline $\begin{array}{l}\text { Hypo/ hyperthyroid- } \\
\text { ism }\end{array}$ & *Impotence & *Infertility \\
\hline IBS & *Liver Dysf. & *Meningitis \\
\hline Metabolic Disorder & $*$ M.S. & *Neoplastic-Tumors \\
\hline Neuralgia & *Neuropathy & *Nephropathy \\
\hline Parkinson's & ${ }^{*}$ Psychiatric disorders & $\begin{array}{c}\text { *Pituitary Dysfunc- } \\
\text { tions }\end{array}$ \\
\hline \multicolumn{3}{|l|}{$\begin{array}{l}\text { Recurrence of Minor } \\
\text { Infections }\end{array}$} \\
\hline Sudden Tachycardia & *Schizophrenia & *Respiratory Failure \\
\hline Stroke & $\begin{array}{c}\text { *Teenage Drug Addic- } \\
\text { tion }\end{array}$ & \\
\hline
\end{tabular}




\section{References}

1. Wagner EK (1999) Herpes Simplex Virus Molecular Biology. In Encyclopedia of Virology, ( $2^{\text {nd }}$ Edn.). In: RG Webster, A Granoff (Eds.). Academic Press, London, England, UK, pp. 686-697.

2. Wagner EK, Garcia Ramirez, JJ Stingley, SW Aguilar, JS Buehler, et al (2002) Practical Approaches to Long Oligonucleotide-Based DNA
Microarray: Lessons From Herpes Viruses. Progress in Nucleic Acids Research 71: 445-492.

3. The Sheikhs Syndrome (2012) IOSR Journal of Dental and Medical Sciences 1(5).

4. (2014) Neuro Invasive Viruses the Silent \& Slow Killers February, 2014 IOSR Journal of Dental and Medical Sciences 13(3). (c) ()

This work is licensed under Creative Commons Attribution 4.0 License

Submission Link: https://biomedres.us/submit-manuscript.php

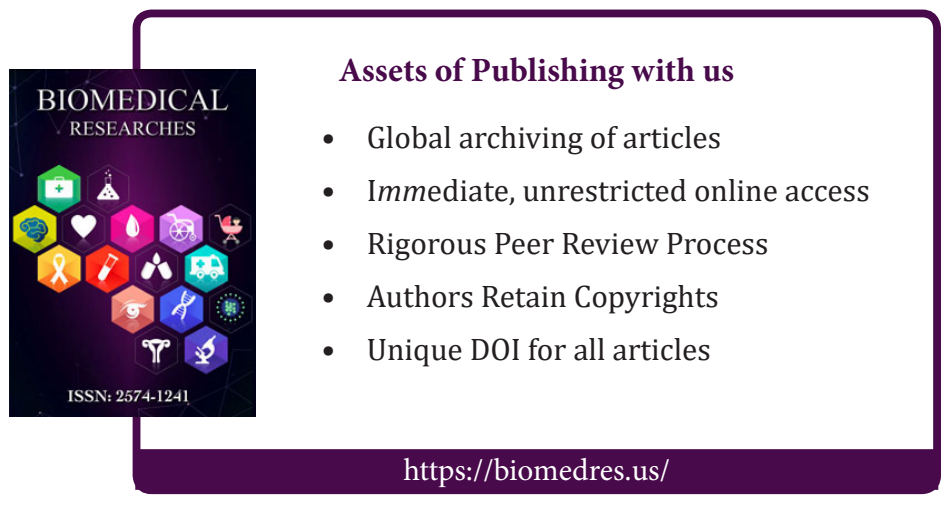

